\title{
Suitable housekeeping genes for normalization of transcript abundance analysis by real-time RT-PCR in cultured bovine granulosa cells during hypoxia and differential cell plating density
}

Vijay S Baddela ${ }^{1}$, Anja Baufeld ${ }^{2}$, Vengala R Yenuganti ${ }^{2}$, Jens Vanselow ${ }^{2 *}$ and Dheer Singh ${ }^{1 *}$

\begin{abstract}
Background: Bovine granulosa cell culture models are important to understand molecular mechanisms of ovarian function. Folliculogenesis and luteinization are associated with increasing density of cells and local hypoxic conditions. The current study identified two reliable housekeeping genes useful for gene normalization in granulosa cells under different in vitro conditions.

Methods: During the current experiments cells were subjected to different biological and physical stimuli, follicle stimulating hormone, different initial cell plating density and hypoxia. Transcript abundance of seven housekeeping genes was quantified by real-time RT-PCR with co-amplification of the respective external standard.

Results: Three of the genes, GAPDH, HMBS, and HPRT1 were found to be regulated by initial cell plating density, five of them, GAPDH, HMBS, HPRT1, RPLPO and RPS18 under hypoxic conditions, but none of them after FSH stimulation. In detail, GAPDH was up regulated, but HPRT1 and HMBS were down regulated at high density and under hypoxia. Expression of RPLPO and RPS18 was inconsistent, but was significantly down-regulated in particular at high cell density combined with hypoxia. In contrast, TBP and B2M genes were neither regulated under different plating density conditions nor by hypoxia as they showed similar expression levels under all conditions analyzed.

Conclusions: The present data indicate that TBP and B2M are appropriate housekeeping genes for normalization of transcript abundance measured by real-time RT-PCR in granulosa cells subjected to different plating densities, oxygen concentrations and FSH stimulation.
\end{abstract}

Keywords: TBP, B2M, GAPDH, HMBS, RPS18, RPLPO, HPRT1, External standards, Co-amplification

\section{Background}

Ovarian follicles can be considered as the basic units of female reproduction. Each ovarian follicle is composed of spherical aggregations of somatic cells (granulosa and theca cells) and a single oocyte. These follicles are periodically initiated to grow, develop and to culminate in the ovulation of usually a single competent oocyte in monovulatory animals like human and bovine [1]. Ovulation is a complex process which is perfectly regulated by endocrine

\footnotetext{
* Correspondence: vanselow@fbn-dummerstorf.de; drdheer.singh@gmail.com ${ }^{2}$ Reproductive Biology, Leibniz Institute for Farm Animal Biology (FBN), Wilhelm-Stahl-Allee 2, 18196 Dummerstorf, Germany

'Animal Biochemistry Division, National Dairy Research Institute, Karnal 132001, Haryana, India
} C) Biomed Central

(c) 2014 Baddela et al.; licensee BioMed Central Ltd. This is an Open Access article distributed under the terms of the Creative Commons Attribution License (http://creativecommons.org/licenses/by/4.0), which permits unrestricted use, distribution, and reproduction in any medium, provided the original work is properly credited. The Creative Commons Public Domain Dedication waiver (http://creativecommons.org/publicdomain/zero/1.0/) applies to the data made available in this article unless otherwise stated. and paracrine acting factors like steroids, gonadotropins and other proteohormones [2]. As the estrus or menstrual cycle progresses towards ovulation, the circulatory levels of gonadotropins, follicle stimulating hormone (FSH) and luteinizing hormone ( $\mathrm{LH})$ increase which further promotes ovulation. We have already shown earlier that granulosa cell (GC) proliferation is increased by FSH and insulin-like growth factor 1 (IGF-I) [3]. As the follicle approaches ovulation, the density of GC increases, but after the preovulatory LH surge, proliferation ceases and GC undergo luteinization thus transforming them from estrogen into progesterone secreting cells [4]. Another important factor associated with the periovulatory perdiod is a change of local oxygen partial pressure. Ovulatory

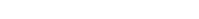


follicles have been shown to undergo hypoxic conditions during the pre-ovulatory stage which is essential for ovulation [5]. Cell density and hypoxia based cell culture experiments are not only important in terms of understanding ovarian physiology during ovulation and luteinization, but may also help to understand cancer cell physiology. Cancer cells rapidly divide and outgrow angiogenic regions of the tumor thus giving rise to regions with significantly lower oxygen partial pressure than found in healthy tissues [6].

It is well established that hypoxia can change gene expression profiles in cultured GC and other cells [7,8]. But also cell density can remarkably change gene expression and cell physiology [9]. In a recent report, we have demonstrated that initial plating density largely effects gene expression, proliferation and hormone production in cultured bovine GC [10].

Gene expression analysis is an important prerequisite to understand cell physiology and metabolism. However, to minimize methodological errors, which might occur during the process of RNA quantification and cDNA synthesis, it is necessary to select reliable housekeeping genes that are not regulated under the different experimental conditions for normalization [11]. Housekeeping genes are constitutively expressed genes whose expression is required to perform basic cellular biological functions for survival and maintaining integrity of the cell [12]. In spite of the fact that glyceraldehyde-3-phosphate dehydrogenase $(\mathrm{GAPDH})$ and $\beta$-actin (ACTB) were routinely used for the normalization of transcript abundance data in real-time RT-PCR experiments, conflicting observations have been reported by various scientific groups regarding their regulation. Both genes have been reported to be regulated differentially in different tissues [13] and even in the same tissue under different physiological conditions [14]. In contrast, in cultured rat cardiosphere-derived cells both genes have been shown as the most stable housekeeping genes under hypoxic conditions [15]. So far however, different housekeeping genes have not been systematically studied under hypoxic as well as differential cell density conditions together or in combination of both. In order to find the most suitable housekeeping genes for the above mentioned experimental treatments in granulosa cells, we tested seven different housekeeping genes encoding the basic transcription factor TATA binding protein (TBP), the metabolic enzymes glyceraldehyde-3-phosphate dehydrogenase (GAPDH), hypoxanthine phosphoribosyltransferase 1 (HPRT1), hydroxymethylbilane synthase (HMBS), the MHC class I cell surface molecule beta-2-microglobulin (B2M), the ribosomal proteins ribosomal protein, large, P0 (RPLP0) and ribosomal protein S18 (RPS18). The co-amplification of external standards with the respective target sequences that was routinely performed during the present study allowed the independent quantification of each of these housekeeping genes under different experimental conditions.

The conditions that we considered for current experiments include, 1) analyzing expression of the housekeeping genes in the presence or absence of FSH with respect to different cell plating density (low and high) and 2) analyzing the expression of housekeeping genes at different oxygen concentrations (normoxic vs. hypoxic) with respect to two different cell plating densities (low and high). GC were cultured under standard serum-free conditions as previously published. In earlier studies it has been shown that under these conditions bovine GC produce estrogen [16] and express the key gene of estrogen biosynthesis, CYP19A1 [17,18], thus suggesting their non-luteinized physiological stage. In our recent paper however, we could demonstrate that high plating density strongly reduced estrogen production and CYP19A1 expression thus suggesting a luteinization-like physiological stage under high density conditions [10].

As housekeeping genes were reported to be regulated differentially in different tissues [19], the present work to characterize the expression of seven different housekeeping genes would be of importance for bovine ovarian somatic cell models based on cell density and hypoxia.

\section{Methods}

\section{Tissue collection, follicular fluid aspiration and granulosa} cell culture

Bovine ovaries were collected from a local slaughterhouse, placed and transported in phosphate buffered Saline (PBS) containing penicillin (100 IU), streptomycin $(0.1 \mathrm{mg} / \mathrm{ml})$ and amphotericin $(0.5 \mu \mathrm{g} / \mu \mathrm{l})$. Before further processing ovaries were washed in PBS with antibiotics and the health status was visually assessed. Follicular fluid along with GC were aspirated from small to medium sized antral follicles $(\leq 6 \mathrm{~mm})$ using sterile, non-toxic, nonpyrogenic 18 gauge needle syringes in PBS and transferred in 15 or $50 \mathrm{ml}$ centrifuge tubes under sterile conditions. $\mathrm{GC}$ were harvested from follicular fluid by centrifugation at 500 RCF for 4 to $6 \mathrm{~min}$ and re-suspended in PBS. Viable cells were counted in a haemocytometer after trypan blue staining. Cells were then pelleted again and resuspended in $90 \%$ fetal calf serum and 10\% DMSO (Roth, Karlsruhe, Germany) for cryopreservation. According to previous experiments the applied cryopreservation regime had no considerable effects on the physiology of thawed GC compared to freshly isolated GC as indicated by steroid production (estrogen, progesterone) and expression of marker transcripts (data not shown). For culturing cells were rapidly thawed at $37^{\circ} \mathrm{C}$, washed and transferred into $\alpha$-MEM containing L-Glutamin ( $2 \mathrm{mM})$, sodium bicarbonate $(0.084 \%)$, BSA (0.1\%), HEPES (20 mM), sodium selenite $(4 \mathrm{ng} / \mathrm{ml})$, transferrin $(5 \mu \mathrm{g} / \mathrm{ml})$, insulin $(10 \mathrm{ng} / \mathrm{ml})$, nonessential amino acids $(1 \mathrm{mM})$, penicillin (100 IU) and 
streptomycin $(0.1 \mathrm{mg} / \mathrm{ml})$. Cells were then seeded on collagen-coated 24 well plates at two different plating densities, low density $\left(1 \times 10^{5}\right.$ cells per well $)$ and high density $\left(1 \times 10^{6}\right.$ cells per well $)$ as described previously [10]. Collagen coating was routinely implemented during this study, because according to previous experiments the number of attached and viable cells was considerably higher and no differences of marker transcript abundance levels were found between coated and uncoated plates [10]. Cells were then subjected to 7 days of basal culture (i.e. without further additives) at $37^{\circ} \mathrm{C}$ and $5 \% \mathrm{CO}_{2}$. Before lysis of cells and RNA preparation cells were subjected to different treatments for 2 additional days. Experiment 1: addition of $20 \mathrm{ng} / \mathrm{ml}$ follicle stimulating hormone (FSH); Experiment 2: change to hypoxic condition $\left(5 \% \mathrm{O}_{2}, 5 \%\right.$ $\mathrm{CO}_{2}, 37^{\circ} \mathrm{C}$ ). In experimental and corresponding control samples media were changed at least every $48 \mathrm{~h}$.

\section{Cell lysis, RNA preparation and cDNA synthesis}

After nine days of incubation RNA was isolated from all samples using the Nucleo Spin ${ }^{\odot}$ RNA II Kit (MachereyNagel, Düren, Germany) following the manufacturer's instructions. Concentration of total RNA was measured three times by using a NanoDrop1000 Spectrophotometer (Thermo Scientific, Bonn, Germany). A total of 250 ng was used for cDNA synthesis using the M-MLV reverse transcriptase, RNasin ribonuclease inhibitor (both Promega), oligo- $(\mathrm{dT})$ primers $(2 \mathrm{ng} / \mu \mathrm{l})$ mixed with random hexamer primers ( $4 \mathrm{ng} / \mu \mathrm{l}$; both Roche, Mannheim, Germany) according to the manufacturer's advice. cDNA was cleaned with the High Pure PCR Purification Kit (Roche) and finally eluted in $50 \mu \mathrm{l}$ of elution buffer.

\section{Quantification of transcripts and of the respective external standards by real-time PCR}

All primers were designed according to reference mRNA sequences by using NCBI's pick primer software (Table 1). Quantification of transcript abundance by real time PCR was performed with SensiFastTM SYBR No-ROX (Bioline, Luckenwalde, Germany) and gene-specific primers (listed in Table 1) in a LightCycler 96 instrument (Roche) with defined cycle conditions (Table 2) and single-point fluorescence acquisition for $10 \mathrm{~s}$. Plasmids of the cloned PCR products of the respective transcripts were used as external standards. Fresh dilutions of corresponding plasmids were prepared $\left(5 \times 10^{-12}\right.$ to $5 \times 10^{-16} \mathrm{~g}$ DNA/reaction) and co-amplified during each real-time PCR run. For amplification of samples $5 \mathrm{ng}$ cDNA were added to final reaction volume of $12 \mu \mathrm{l}$. The co-amplification of standards allowed the determination of the copy number of transcripts relative to the amount of total RNA previously subjected to cDNA synthesis.
Table 1 Details of primers used for real-time RT-PCR

\begin{tabular}{|c|c|c|}
\hline Symbol & Name & Sequence \\
\hline \multirow[t]{2}{*}{$B 2 M$} & \multirow[t]{2}{*}{ Beta-2-microglobulin } & F:ACGCTGAGTTCACTCCCAACAGCAA \\
\hline & & R:TCGATGGTGCTGCTTACAGGTCTCG \\
\hline \multirow[t]{2}{*}{ GAPDH } & \multirow{2}{*}{$\begin{array}{l}\text { Glyceraldehyde-3-phosphate } \\
\text { dehydrogenase }\end{array}$} & F:AGCGAGATCCTGCCAACATCAAG \\
\hline & & R:GCAGGAGGCATTGCTGACAATCT \\
\hline \multirow[t]{2}{*}{ HMBS } & \multirow{2}{*}{$\begin{array}{l}\text { Hydroxymethylbilane } \\
\text { synthase }\end{array}$} & F:CAGCATGAAGATGGCCCTGAAGATG \\
\hline & & R:CTCAGGTAGCAGAGGGCTGGGATGT \\
\hline \multirow[t]{2}{*}{ HPRT1 } & \multirow{2}{*}{$\begin{array}{l}\text { Hypoxanthine } \\
\text { phosphoribosyltransferase } 1\end{array}$} & F:TGAAAAGGACCCCTCGAAGTGTTGG \\
\hline & & R:CGCCAGGTATTTCCAAACTCAACTCG \\
\hline \multirow[t]{2}{*}{ RPLPO } & \multirow{2}{*}{$\begin{array}{l}\text { Ribosomal protein, } \\
\text { large, PO }\end{array}$} & F:TGGTTACCCAACCGTCGCATCTGTA \\
\hline & & R:CACAAAGGCAGATGGATCAGCCAAG \\
\hline \multirow[t]{2}{*}{ RPS18 } & \multirow[t]{2}{*}{ Ribosomal protein $\mathrm{S18}$} & F:GAGGTGGAACGTGTGATCACCATT \\
\hline & & R: TGTATTTCCCGTCCTTCACGTCCT \\
\hline \multirow[t]{2}{*}{$T B P$} & \multirow[t]{2}{*}{ TATA box binding protein } & F: GCCTTGTGCTTACCCACCAACAGTTC \\
\hline & & R: TGTCTICCTGAAACCCTTCAGAATAGGG \\
\hline
\end{tabular}

\section{Statistical analysis}

GraphPad prism 5.0 software was used for analysing the results with two way ANOVA. Post hoc test were performed by using quickcals post test calculator to find the significance $(\mathrm{p}<0.05)$ among variables.

\section{Results}

Effects of FSH treatment and of different cell plating density on housekeeping gene expression

Three of the analyzed housekeeping genes were significantly regulated by differential plating density, with GAPDH showing up-, but $H M B S$ and HPRT1 down-regulation (Figure 1a,d and g). None of the genes was significantly affected by FSH treatment, however, expression of the ribosomal protein encoding genes RPS18 and RPLPO seems to be marginally, but not significantly stimulated by FSH (Figure 1e and f). Only B2M and TBP (Figure $1 \mathrm{~b}$ and $\mathrm{c}$ ) did not show any regulation under different plating conditions or hormonal stimulation.

Table 2 Real-time PCR conditions

\begin{tabular}{llll}
\hline Step & Description & Temperature & Time \\
\hline 1 & Pre-incubation & $95^{\circ} \mathrm{C}$ & $5 \mathrm{~min}$ \\
2 & Denaturation & $95^{\circ} \mathrm{C}$ & $20 \mathrm{sec}$ \\
3 & Annealing & $60^{\circ} \mathrm{C}$ & $15 \mathrm{sec}$ \\
4 & Extension & $72^{\circ} \mathrm{C}$ & $15 \mathrm{sec}$ \\
5 & Melting & $95^{\circ} \mathrm{C}$ & $5 \mathrm{sec}$ \\
& & $70^{\circ} \mathrm{C}$ & $60 \mathrm{sec}$ \\
& & $97^{\circ} \mathrm{C}$ & $1 \mathrm{~s}$ (continuous acquisition) \\
\hline
\end{tabular}




\section{Effects of hypoxia and different cell plating density on housekeeping gene expression}

Under hypoxic (5\% O2) compared to normoxic (20\% O2) conditions, five of the genes showed significant regulation: GAPDH was strongly up-regulated (Figure 2a) in low and high density cultures. In contrast, the abundance of $H M B S$, RPS18, RPLPO and of HPRT1 transcripts was lower under hypoxic conditions (Figure 2d,e,f, and g), however, in case of both ribosomal protein encoding genes, only in high (Figure 2e and f) and in case of $H M B S$ only in low density cultures (Figure 2d). As for density effects and FSH stimulation, only $B 2 M$ and in particular TBP did not show significant regulation under these experimental conditions (Figure $2 \mathrm{~b}$ and $\mathrm{c}$ ).

\section{Discussion}

Appropriate normalization of real time RT-PCR data is important for transcript quantification [20]. The reliability and reproducibility of any real time RT-PCR data can be improved by including an invariant endogenous control gene (reference gene) in the assay for preventing sample to sample variations. This helps to avoid unintentionally biased data caused by varying efficiency of sample preparation such as RNA quantification, RNA integrity differences, differences in efficiency of reverse transcription and cDNA sample loading differences. Therefore, meaningful reports of any mRNA expression data require accurate and relevant normalization to some standard gene or internal control gene [21]. However, the validity of the normalization procedure largely depends on the normalizer (housekeeping gene) itself. It is of high importance to choose an appropriate control gene based on its property to maintain constant levels of expression between samples, regardless of the experimental condition. This is especially relevant when the samples have been obtained from different



Figure 1 Effects of FSH and different cell plating density on transcript abundance in cultured bovine granulosa cells. The expression of GAPDH (a), B2M (b), TBP (c), HMBS (d), RPS18 (e), RPLPO (f) and HPRT1 (g) was analyzed under FSH treatment at low and high initial cell plating density. Copy numbers were calculated and normalized to initial amounts of RNA used for CDNA preparation. Values are means \pm SEMs of three independent cultures. Bars with different letters are significantly different from each other. 


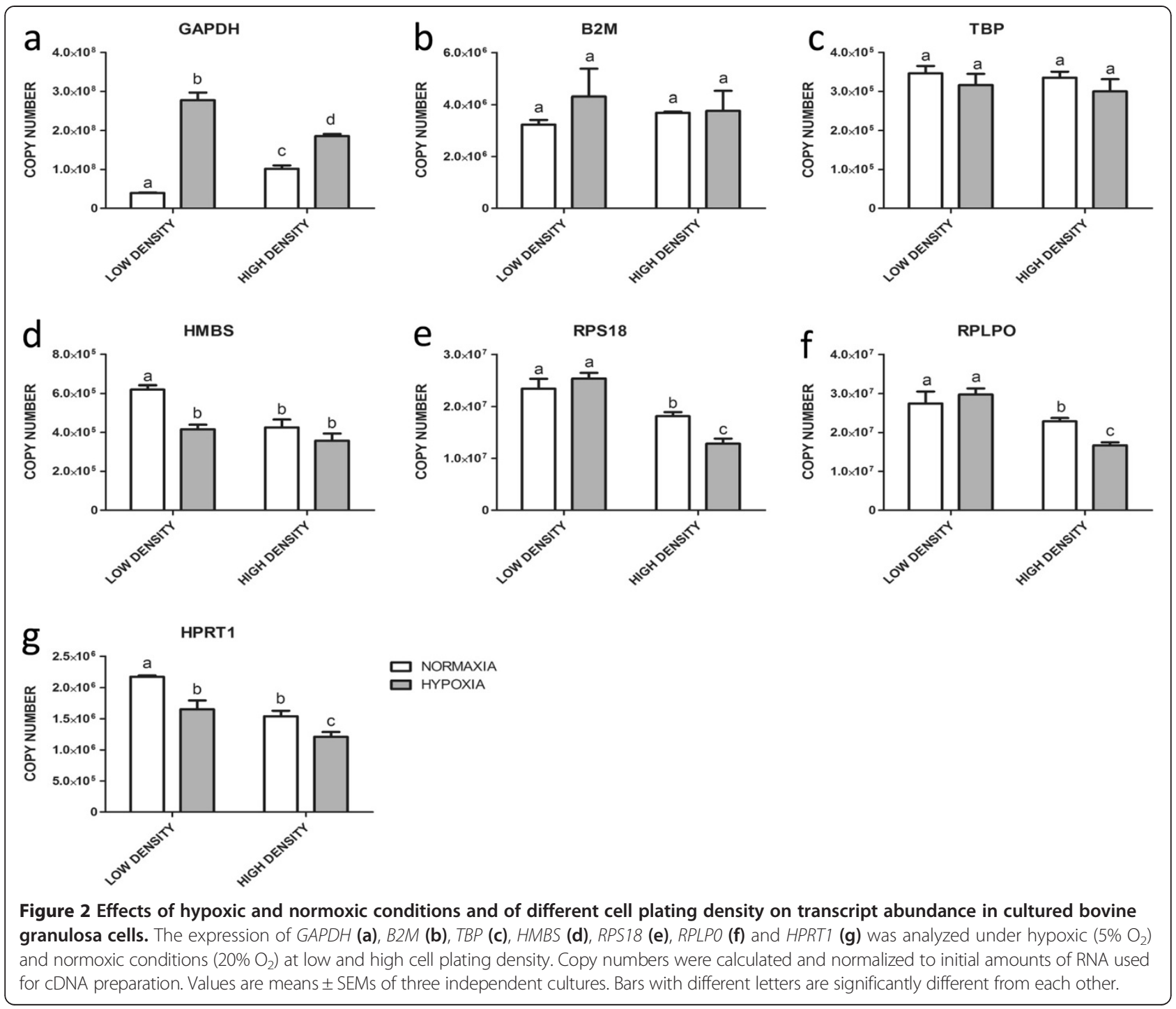

individuals, different tissues and/or different stages of development.

During the present study we observed significantly higher levels of GAPDH transcript abundance in samples plated at high compared to low density and even a massive increase of GAPDH expression under hypoxic conditions. These observations are in line with the view that high density of cells might create a local hypoxic microenvironment. Hypoxia can induce up-regulation of glycolysis [22] as electron transport system stops or slows down because of a lack of sufficient oxygen supply [23]. Consequently, this may lead to an increase of GAPDH transcripts. Therefore, the use of GAPDH as a housekeeping gene for normalization under direct (incubation under hypoxic conditions) or indirect (high cell density) hypoxic conditions will definitely lead to an experimental bias of relative gene expression data. Similar to GAPDH, also HPRT1 and HMBS showed differential expression, however in the opposite direction i.e. down-regulation under hypoxic and high plating density conditions. HPRT1 is involved in nucleotide biosynthesis. Given high cellular plating density or hypoxic conditions, the cellular proliferation decreases [10], which may lead to reduced expression of genes involved in nucleotide metabolism. The observed down-regulation of $H M B S$ is also well in line with a previous study reporting that hypoxia decreases $H M B S$ transcript abundance in human hepatic cell lines under hypoxic conditions [24]. Both genes encoding ribosomal proteins, RPS18 and RPLPO, also do not show consistent expression under the present experimental conditions. We found down-regulation at high density and hypoxic conditions. The expressions of both genes also depends on the proliferative activity of the cells [25] which is definitely reduced at high density [10] and might be also reduced under direct hypoxic conditions. This is in line with the view of reduced protein synthesis under hypoxic and 
high cell density conditions and thus with reduced expression of ribosomal proteins.

In contrast to all other housekeeping genes investigated, only $T B P$ and $B 2 M$ showed a stable and constant expression irrespective of cellular plating density, oxygen partial pressure and FSH stimulation. TBP is an indispensable basal transcription factor which is primarily recruited to the promoter TATA box to initiate transcription by RNA polymerase-II [26]. As the basal level transcription is essential for all cellular physiological conditions, TBP expression might not be subjected to significant regulation. $B 2 M$ is a cell surface marker for all nucleated cells as a component of MHC1 [27]. The expression of $B 2 M$ usually remains constant in cultured cells unless stimulation with B-cell derived cytokines [28] to promote the synthesis of MHC1. These results seem contradictory to a previous study reporting that in cultured rat cardiospherederived cells TBP is the least, but GAPDH the most stable housekeeping gene under hypoxic condition. This clearly points out that the suitability of housekeeping genes for normalization has to be tested and adapted for each experimental approach.

\section{Conclusions}

The transcript quantification with the respective external standards of different housekeeping genes revealed that HPRT1, HMBS, RPLPO, RPS18, and in particular the commonly used GAPDH were differentially regulated at differential cell density and different oxygen concentrations. Hence these genes are not appropriate to be used as normalizers in real time RT-PCR experiments under hypoxia. In contrast, $B 2 M$ and $T B P$ showed consistent expression levels under all experimental conditions. Therefore, we conclude that only $B 2 M$ and $T B P$ are appropriate for normalization in bovine ovarian granulosa cells under FSH stimulation, differential oxygen concentrations and varying cell density.

\section{Abbreviations}

ACTB: $\beta$-actin; B2M: MHC class I cell surface molecule beta-2-microglobulin; DMSO: Dimethylsulfoxide; FSH: Follicle stimulating hormone;

GAPDH: Glyceraldehyde-3-phosphate dehydrogenase; GC: Granulosa cells; HMBS: Hydroxymethylbilane synthase; HPRT1: Hypoxanthine

phosphoribosyltransferase 1; IGF-I: Insulin-like growth factor 1; LH: Luteinizing hormone; MEM: Minimum essential media; PBS: Phosphate buffered saline; RPLPO: Ribosomal protein, large, P0; RPS18: Ribosomal protein S18; RT-PCR: Reverse transcripton - polymerase chain reaction; TBP: TATA binding protein.
}

\section{Competing interests}

The authors declare that they have no competing interests.

\section{Authors' contributions}

VSB, DS and JV conceived and designed the experiments, and wrote the paper. VSB, VRY and AB performed the experiments. All authors read and approved the final manuscript.

\section{Acknowledgements}

Authors express sincere thanks to DST (India) and DAAD (Germany) for funding this Indo-German collaborative project (Projekt-ID 55516734). Authors also thank Veronica Schreiter and Maren Anders for their helping hands during lab work.

Received: 6 October 2014 Accepted: 19 November 2014 Published: 27 November 2014

\section{References}

1. Lucy MC: The bovine dominant ovarian follicle. J Anim Sci 2007, 85:E89-E99.

2. Russell DL, Robker RL: Molecular mechanisms of ovulation: co-ordination through the cumulus complex. Hum Reprod Update 2007, 13:289-312.

3. Monga R, Sharma I, Datta TK, Singh D: Characterization of serum-free buffalo granulosa cell culture and analysis of genes involved in terminal differentiation from FSH- to LH-responsive phenotype. Domest Anim Endocrinol 2011, 41:195-206.

4. Murphy BD: Luteinization. In The ovary. 2nd edition. Edited by Leung PC, Adashi EY. Burlington, MA: Academic Press; 2004:185-199.

5. Kim J, Bagchi IC, Bagchi MK: Signaling by hypoxia-inducible factors is critical for ovulation in mice. Endocrinology 2009, 150:3392-3400.

6. Neeman M, Abramovitch R, Schiffenbauer YS, Tempel C: Regulation of angiogenesis by hypoxic stress: from solid tumours to the ovarian follicle. Int J Exp Pathol 1997, 78:57-70.

7. Fadhillah, Yoshioka S, Nishimura R, Okuda K: Hypoxia promotes progesterone synthesis during luteinization in bovine granulosa cells. J Reprod Dev 2014, 60:194-201.

8. Chi JT, Wang Z, Nuyten DS, Rodriguez EH, Schaner ME, Salim A, Wang Y, Kristensen GB, Helland A, Borresen-Dale AL, Giaccia A, Longaker MT, Hastie T, Yang GP, van de Vijver MJ, Brown PO: Gene expression programs in response to hypoxia: cell type specificity and prognostic significance in human cancers. PLoS Med 2006, 3:e47.

9. Portela VM, Zamberlam G, Price CA: Cell plating density alters the ratio of estrogenic to progestagenic enzyme gene expression in cultured granulosa cells. Fertil Steril 2010, 93:2050-2055.

10. Baufeld A, Vanselow J: Increasing cell plating density mimics an early post-LH stage in cultured bovine granulosa cells. Cell Tissue Res 2013, 354:869-880.

11. De Kok JB, Roelofs RW, Giesendorf BA, Pennings JL, Waas ET, Feuth T, Swinkels DW, Span PN: Normalization of gene expression measurements in tumor tissues: comparison of 13 endogenous control genes. Lab Invest 2005, 85:154-159.

12. Eisenberg E, Levanon EY: Human housekeeping genes, revisited. Trends Genet 2013, 29:569-574.

13. Kouadjo KE, Nishida Y, Cadrin-Girard JF, Yoshioka M, St-Amand J: Housekeeping and tissue-specific genes in mouse tissues. BMC Genomics 2007, 8:127.

14. Glare EM, Divjak M, Bailey MJ, Walters EH: beta-Actin and GAPDH housekeeping gene expression in asthmatic airways is variable and not suitable for normalising mRNA levels. Thorax 2002, 57:765-770.

15. Tan SC, Carr CA, Yeoh KK, Schofield CJ, Davies KE, Clarke K: Identification of valid housekeeping genes for quantitative RT-PCR analysis of cardiosphere-derived cells preconditioned under hypoxia or with prolyl-4-hydroxylase inhibitors. Mol Biol Rep 2012, 39:4857-4867.

16. Gutierrez CG, Campbell BK, Webb R: Development of a long-term bovine granulosa cell culture system: induction and maintenance of estradiol production, response to follicle- stimulating hormone, and morphological characteristics. Biol Reprod 1997, 56:608-616.

17. Sahmi F, Nicola ES, Zamberlam GO, Goncalves PD, Vanselow J, Price CA: Factors regulating the bovine, caprine, rat and human ovarian aromatase promoters in a bovine granulosa cell model. Gen Comp Endocrinol 2014, 200:10-17.

18. Hamel M, Vanselow J, Nicola ES, Price CA: Androstenedione increases cytochrome P450 aromatase messenger ribonucleic acid transcripts in non-luteinizing bovine granulosa cells. Mol Reprod Dev 2005, 70:175-183.

19. Thorrez L, Laudadio I, Van DK, Quintens R, Hendrickx N, Granvik M, Lemaire K, Schraenen A, Van Lomel L, Lehnert S, Aguayo-Mazzucato C, Cheng-Xue R, Gilon P, Van Mechelen I, Bonner-Weir S, Lemaigre F, Schuit F: Tissue-specific disallowance of housekeeping genes: the other face of cell differentiation. Genome Res 2011, 21:95-105. 
20. Guenin S, Mauriat M, Pelloux J, Van WO, Bellini C, Gutierrez L: Normalization of qRT-PCR data: the necessity of adopting a systematic, experimental conditions-specific, validation of references. J Exp Bot 2009, 60:487-493.

21. Aggarwal J, Sharma A, Kishore A, Mishra BP, Yadav A, Mohanty A, Sodhi M, Kataria RS, Malakar D, Mukesh M: Identification of suitable housekeeping genes for normalization of quantitative real-time PCR data during different physiological stages of mammary gland in riverine buffaloes (Bubalus bubalis). J Anim Physiol Anim Nutr (Berl) 2013, 97:1132-1141.

22. Naughton DP: Hypoxia-induced upregulation of the glycolytic enzyme glucose-6-phosphate isomerase perpetuates rheumatoid arthritis. Med Hypotheses 2003, 60:332-334

23. Bell EL, Chandel NS: Genetics of mitochondrial electron transport chain in regulating oxygen sensing. Methods Enzymol 2007, 435:447-461.

24. Vargas PD, Furuyama K, Sassa S, Shibahara S: Hypoxia decreases the expression of the two enzymes responsible for producing linear and cyclic tetrapyrroles in the heme biosynthetic pathway. FEBS J 2008, 275:5947-5959.

25. Naora H: Involvement of ribosomal proteins in regulating cell growth and apoptosis: translational modulation or recruitment for extraribosomal activity? Immunol Cell Biol 1999, 77:197-205.

26. Kornberg RD: The molecular basis of eukaryotic transcription. Proc Natl Acad Sci U S A 2007, 104:12955-12961.

27. Gussow D, Rein R, Ginjaar I, Hochstenbach F, Seemann G, Kottman A, Ploegh HL: The human beta 2-microglobulin gene. Primary structure and definition of the transcriptional unit. J Immunol 1987, 139:3132-3138.

28. Coccia E, Marziali G, Fiorucci G, Romeo G, Affabris E, Battistini A, Rossi GB: Transcriptional induction of $\mathrm{H} 2$ (class I) antigens and beta 2 microglobulin by interferon-gamma in interferon-sensitive and interferon-resistant Friend leukemia cells. J Biol Regul Homeost Agents $1992,6: 21-25$

doi:10.1186/1477-7827-12-118

Cite this article as: Baddela et al:: Suitable housekeeping genes for normalization of transcript abundance analysis by real-time RT-PCR in cultured bovine granulosa cells during hypoxia and differential cell plating density. Reproductive Biology and Endocrinology 2014 12:118.

\section{Submit your next manuscript to BioMed Central and take full advantage of:}

- Convenient online submission

- Thorough peer review

- No space constraints or color figure charges

- Immediate publication on acceptance

- Inclusion in PubMed, CAS, Scopus and Google Scholar

- Research which is freely available for redistribution 